\title{
Key-phrase Allusions and Their Translations: A Focus on Mathnawi
}

\author{
Akram Khadem $^{1}$ \& Hossein Vahid Dastjerdi ${ }^{1}$ \\ ${ }^{1}$ Department of English Language, University of Isfahan, Isfahan, Iran \\ Correspondence: Akram Khadem, Department of English Language, University of Isfahan, Isfahan, Iran. E-mail: \\ Khadem.akram@gmail.com
}

Received: April 27, 2012 Accepted: May 9, 2012 Online Published: August 17, 2012

doi:10.5539/ass.v8n11p178 URL: http://dx.doi.org/10.5539/ass.v8n11p178

\begin{abstract}
The purpose of this study is to focus on the translation of Key-Phrase allusions in "The wolf and the fox go to the hunt in attendance on the lion", one of the poems of Mathnawi in book one. The translations are the ones by Mojaddedi (2004) and Redhouse (1881).The researchers aim to compare Key-Phrase allusions in this poem in Persian with their translations in English. Then, according to the strategies proposed by Leppihalme (1997), they plan to discover which of the strategies are observed by the translators and why. As most of the Key-Phrase allusions in Mathnawi are verses of Koran or some parts of the verses, there seems a specific relation exists between this type KP allusions and the choice of the strategies.
\end{abstract}

Keywords: allusions, proper-noun allusions, key-phrase allusions, religious allusions

\section{Introduction}

Allusion is a reference to another work of literature, to a person, an event etc. In a close look at literature, we will observe that allusions have a specific role in stories and poems. Allusions are mostly used as help to the authors to simplify persuading their readers for accepting the message they want to convey. Among the works of literature, Mathnawi is full of allusions, both Proper noun (PN) and Key-Phrase allusions (KP).

\subsection{Mathnawi}

Masnavi-I Ma'navi (Persian: مثنوى معنوى) or Mesnevi (Turkish), which is also written Mathnawi, Ma'navi, or Mathnavi, is an extensive poem written in Persian by Jalal-al-Din Muhammad Rumi. Mathnavi consists of 6 books that each has 25,000 verses or 50,000 lines. As Mojaddedi (2004) puts it,

"Rumi has long been recognized within the Sufi tradition as one of the most important Sufis in history. He not only produced the finest Sufi poetry in Persian, but was the master of disciples who later named their order after him. Moreover, by virtue of the intense devotion he expressed towards his own master, Rumi has become the archetypal Sufi disciple. From that perspective, the unprecedented level of interest in Rumi's poetry over the last couple of decades in North America and Europe does not come as a total surprise. Once his poetry finally began to be rendered into English in an attractive form, which coincided with an increased interest in mysticism among readers, this Sufi saint who expressed his mystical teachings in a more memorable and universally accessible form than any other started to become a household name" (p. XI).

Mathnawi is translated to English by different translators, to name a few: Redhouse (the first book only), Winfield, Wilson (book I I), Nicholson, Mojaddedi (book 1\&2).

\subsection{Definition of Allusion}

If we look at the etymology of the term 'allusion' we can see a connection with the idea of play: ad + ludere ®alludere (Leppihalme, 1997).

There are different definitions for the concept of allusion by different scholars:

As Wheeler (1979, p.5) puts it, "Allusion helps to elucidate the meaning of each text and to indicate the literary modes and conventions in which its author works."

According to Leppihalme (1997), Standard definitions in literary studies share the idea of 'reference to something'. She has mentioned different definitions in encyclopedias or dictionaries and they are:

"ALLUSION. Latin alludere, to play with, to jest, to refer to. A reference to characters and events of mythology, 
legends, history (Scott, 1965)

ALLUSION. Tacit reference to another literary work, to another art, to history, to contemporary figures, or the like. (Preminger, 1965)

A reference, usually brief, often casual, occasionally indirect, to a person, event, or condition presumably familiar but sometimes obscure or unknown to the reader. (Shaw, 1976)

A reference, explicit or indirect, to a person, place, or event, or to another literary work or passage (Abrams, 1984)" (cited in Leppihalme, 1997, p.6).

Leppihalme (1997) believes that such reference is made in order to compare A and B because according to Lass et al (1987) 'An allusion is a figure of speech that compares aspects or qualities of counterparts in history, mythology, scripture, literature, popular or contemporary culture'(as cited in Leppihalme, 1997, p.6) .According to Niknasab (2011) "allusion moves in only one direction: if A alludes to B, then B does not allude to A".

Ruokonen (2010) has mentioned the salient characteristics of allusions and they are :

“1) Allusion is a reference conveying implicit meaning by means of activating its referent text or a part of it (a more specific referent or connotations).

2) Allusion may take an implicit or explicit form, but it must bear a sufficient resemblance to its referent so as to be recognizable.

3) The referent belongs to assumed shared knowledge, which is presumably familiar to the author and at least some of his/her readers." (p.33)

\subsection{Culture Bumps}

As leppihalme(1997) says ,allusion is a kind of "culture bump'. "They are expected to convey a meaning that goes beyond the mere words used." (p.viii). As culture-bound elements, allusions depend largely on familiarity to convey meaning (Leppihalme, 1997, P.viii).

Carol M. Archer (1986, pp.170-1) has used the term 'culture bump' and it refers to the kind of problems which happen in intercultural communication. But it is not as serious as culture shock (cited in Leppihalme, 1997) .Carol M. Archer says: 'A culture bump occurs when an individual finds himself or herself in a different, strange, or uncomfortable situation when interacting with persons of a different culture'. Carol M. Archer believes that culture bumps happen between speakers who are of different cultural background.

Cordero (1984, p.473) believes that the translation problems which are related to culture bumps are more serious than the ones related to the semantic or syntactic difficulties of a text.

\subsection{Intertexuality}

Allusion and intertexuality are two related words. Intertextuality was coined by Julia Kristeva in 1969 (in Montgomery, 2000, p.160).It refers to different ways that texts interact with other texts.it means that we do not regard texts as separate from each other they are made of other texts both known and unknown. "Allusion is a form of intertextuality that works largely through verbal echoes between texts" (Montgomery, 2000, p.161).

\subsection{Types of Allusions}

\subsubsection{Proper Name (PN) Allusions and Key-Phrase (KP) Allusions}

Leppihalme (1997) has divided allusions into two groups: proper name allusion and key-phrase allusion. In PN allusions a name is mentioned, but in KP allusions no name is mentioned but instead there's a phrase that refers to that name.

PN allusions: According to Leppihalme (1997) PN allusions can be real-life and fictional figures, the international names of entertainers or politicians, the famous names of past generations, writers, painters and so on. These kinds of names are sometimes borrowed from Holy Scriptures or myths. For example in Mathnawi most of the religious PN are names of prophets which are mentioned in Holy Koran.

KP allusions: Leppihalm (1997) believes that "Bible is the most common single source of key-phrase allusions". She has mentioned other sources and they are: Nursery rhymes and children's tales, songs, well-known films and topical television programs ,political slogans ,Commercial product slogans, Various catch-phrases, clichés and proverbs, Various popular beliefs, assumptions and stories ,A writer's own experiences may function as sources of private allusions.

KP allusions abound in Mathnawi and they are borrowed from Koran or what the prophets have said. 
1.5.2 Kirillove (2003) Has Categorized Allusions into Five Groups:

$\checkmark$ Historical allusion (such as people, places, events)

$\checkmark$ Literary allusion (such as characters, settings, plot)

$\checkmark$ Biblical allusion (including texts from Old Testament, New Testament);

$\checkmark$ Popular culture (related to contemporary people, places, events, literary works, works of art)

$\checkmark \quad$ The arts (related to music, works of art, theatre/film) (cited in Niknasab (2011).

There is another division extracted from the thesis of Sahebhonar (2006) and that is: religious allusion, mythological allusion, literary allusion, and historical allusion.

\subsection{The Recognizability of Allusions}

Lepphiham believes that the recognition of the source of KP allusions strongly depends on familiarity. If the reader has heard a phrase repeatedly since childhood, read in books, heard in churches, at school, in songs they listen to, in films and television programs etc. then s/he will easily recognize them and their sources.

Lepphiham has mentioned that sometimes there is no familiarity, so there are other ways for the recognition of that allusion: deviations in spelling, lexis, grammar or style, quotation marks or some other 'extra-allusive' devices, the length of the phrase , an introductory phrase such as 'they say'.

\subsection{Strategies for Translating Allusions}

As Leppihalme (1997) says, it is necessary that the translator be able to recognize the allusions in the text s/he wants to translate and pause to find the appropriate strategy for translating them. Leppihalme(1997) has recommended different strategies for translating allusions. She says that the potential translation strategies for PN and KP allusions are somewhat different because it is possible for the translator to keep a PN unchanged, while a KP allusion need a change in wording. But there are some commonalities between the strategies for translating these two groups and they are keeping the allusion, changing it somehow and omitting the allusion.

\subsubsection{The Strategies for Translating PN Allusions According to Leppihalme (1997, P.79)}

(1) Retention of name (either unchanged or in its conventional TL form,); with three subcategories:

(1a) use the name as such;

(1b) use the name, adding some guidance

(1c) use the name, adding a detailed explanation, for example a footnote.

(2) Replacement of name by another (beyond the changes required by convention); with two subcategories:

(2a) replace the name by another SL name;

(2b) replace the name by a TL name.

(3) Omission of name; with two subcategories:

(3a) omit the name but transfer the sense by other means, for example by a common noun;

(3b) omit the name and the allusion altogether.

1.7.2 The Potential Strategies for translating KP Allusions According to Leppihalme (1997, P.84)

A Use of a standard translation;

B Minimum change, that is, a literal translation, without regard to connotative or contextual meaning there is thus no change that would aim specifically at the transfer of connotations;

C Extra-allusive guidance added in the text, where the translator follows his/her assessment of the needs of TT readers by adding information (on sources etc.) which the author, with his/her SL viewpoint, did not think necessary; including the use of typographical means to signal that the material is preformed;

D The use of footnotes, endnotes, translator's prefaces and other explicit explanations not slipped into the text but overtly given as additional information;

E Simulated familiarity or internal marking, that is, the addition of intra-allusive allusion-signaling features (marked wording or syntax) that depart from the style of the context, thus signaling the presence of borrowed words;

F replacement by a preformed TL item; 8 
G Reduction of the allusion to sense by rephrasal, in other words, making its meaning overt and dispensing with the allusive KP itself;

$\mathrm{H}$ Re-creation, using a fusion of techniques: creative construction of a passage which hints at the connotations of the allusion or other special effects created by it;

I Omission of the allusion.

In addition to the above, she has mentioned that there are two other strategies which are seldom used; One of them as she puts it is: "throwing up of one's hands in desperation, stating that there are allusive meanings involved which are beyond translation (with no attempt to explain what they are)" (p.84).As she says this strategy does not exist in the list because it can rarely be used when translating books or newspaper articles. The second strategy is to bring the allusion to the target text as it is in its source-text form.

\subsection{Review of Literature}

Reviewing literature the following was found:

In a research on allusions, Vahid Dastjerdi and Sahebhonar (2008) have analyzed Personal PN allusions in the first Book of Mathnawi (1207-1273) .In the analysis of the translations by Redhouse (1881) and Nicholson (1940) and with the consideration of Leppihalme's proposed strategies, they have found that the most common strategies are 'retention without any guidance'.Another finding is that whenever other strategies have been employed, a kind of loss of allusive connotations is somehow inevitable.

Pirnajmuddin and Niknasab (2011) have explored the kind of strategies which are used in the translation of allusions, both PN and KP, in 'A Portrait of the Artist as a Young Man 'by Badi'ei (1380), Dariush (1370) and Jooya (1382).The same as Vahid Dastjerdi and Sahebhonar (2008), they have used Leppihalme's strategies. They have found that 'retention of the given name' is of the highest and 'omission' of the lowest frequency in the translations.

Bahrami (2012) has investigated the translation of allusions in the poems of Hafiz. She has focused on the kind of strategies( Leppihalme's strategies) which are used by Clark (1891) in translating PN and KP allusions. She has found that the most common strategy which is used for the translation of PN allusions is 'retention without any guidance' and for key-phrase allusions is 'literal translation with minimum change'. Bahrami (2012) believes the translator's preference on the one hand shows that the translator has wished to be faithful to the source texts but one the other hand, the connotations are ignored by the translator.

\section{The Study}

As it was observed above, some of the researchers have focused just on PN allusions and some on both PN and KP allusions in different pieces of work, but none of them have focused on the translation of KP allusions in Mathnawi.The present study aims to Compare KP allusions in one of the poems in Mathnawi, named "The wolf and the fox go to the hunt in attendance on the lion" with their translations in English by Mojaddedi (2004) and Redhouse (1881).Leppihalme's (1997) proposed strategies are used as a base for comparison. The researchers plan to see whether the strategies of Leppihame are observed in these translations and which of them has been used more than the others.

\section{Method}

The corpus of the study consists of one of the poems of Mathnavi and two translations of it by Mojaddedi (2004) "The wolf and the fox go to the hunt in attendance on the lion", and Redhouse(1881), "The lion's hunt in company". All the examples of KP allusions extracted from this poem are mostly verses from Koran and traditions (Hadiths) by the prophets or Imams. The translated forms in English are compared with their source texts in Persian to see what kinds of strategies are used in the translation of KP allusion. The comparison is done based on Leppihalme's strategies for translating KP allusions. Then the parts which include KP allusions are separated in tables and after that, in a descriptive analysis, the frequency of the use of strategies are counted.

\section{Data Analysis and Results}

In an analysis of "The wolf and the fox go to the hunt in attendance on the lion", only $11 \mathrm{KP}$ allusions were found and they were all religious ones which are either verses from Koran or traditions (Hadiths) by the prophets or Imams. Then, each of the couplets which included those allusion were separated in a table with their two translations in English by Mojaddedi(2004) and Redhouse(1881). After the comparison of the allusions in the ST with their translations in TT, the translation strategies were found according to Leppihalme's strategies. At the end, the frequency of the kind of strategies was counted which can be seen in tables 12 and 13 
Note: The footnotes or the endnotes which are mentioned by the translators can be seen at the end of the tables.

Table 1.

\begin{tabular}{ll}
\hline No: 3017 & \\
&
\end{tabular}

T:Mojaddedi For such kings feel they're burdened by their troops,

But he agreed, for blessings come from groups:

T:Redhouse

A king feels inconvenienced by throngs of troops;

But out of kindness makes them share his warlike swoops

St. G

\begin{tabular}{|c|c|c|}
\hline \multirow[t]{2}{*}{ No: 3019} & امر شَاورْهُمْ بِيمبر را رسيد & \\
\hline & كر جه ر ايى نيست رايش را نديد & \\
\hline \multirow[t]{2}{*}{ T:Mojaddedi } & Was not the Prophet told, 'Consult them too!' * & Str. $\mathrm{C} / \mathrm{D}$ \\
\hline & Though no one had as good a point of view, & \\
\hline \multirow[t]{2}{*}{$\mathrm{T}:$ Redhouse } & 'Twas God's command to Ahmed still: "With them consult." 1 & \\
\hline & True, they gave no advice; no counsel did result. & St. C/D \\
\hline
\end{tabular}

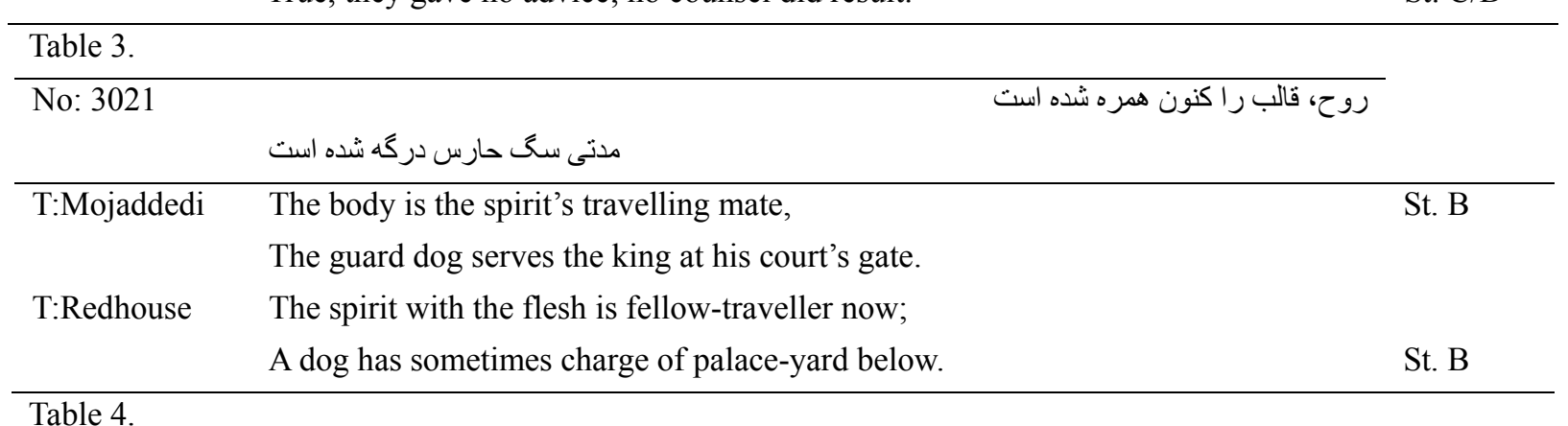

\begin{tabular}{|c|c|}
\hline No: 3037 & ظانين باله ظن السوء را \\
\hline & \\
\hline
\end{tabular}

\begin{tabular}{lll}
\hline T:Mojaddedi & Those who think ill of God, ${ }^{*}$ if I don't break & St. C/D \\
& And chop their heads, then that is my mistake! & \\
T:Redhouse & 'They who conceive an evil thing of God' 1 are cursed; & St. C/D
\end{tabular}

Table 5 .

No: 3041 فقر و رنجورى به استت اى سند

كان تبسم دام خود را بر كند

T:Mojaddedi Becoming poor is best for you who're sure Str. G About wealth's worth - it soon sheds its allure.

T:Redhouse Through poverty and suffering we may escape St. G

The trap that riches bait; and so avoid the scrape.

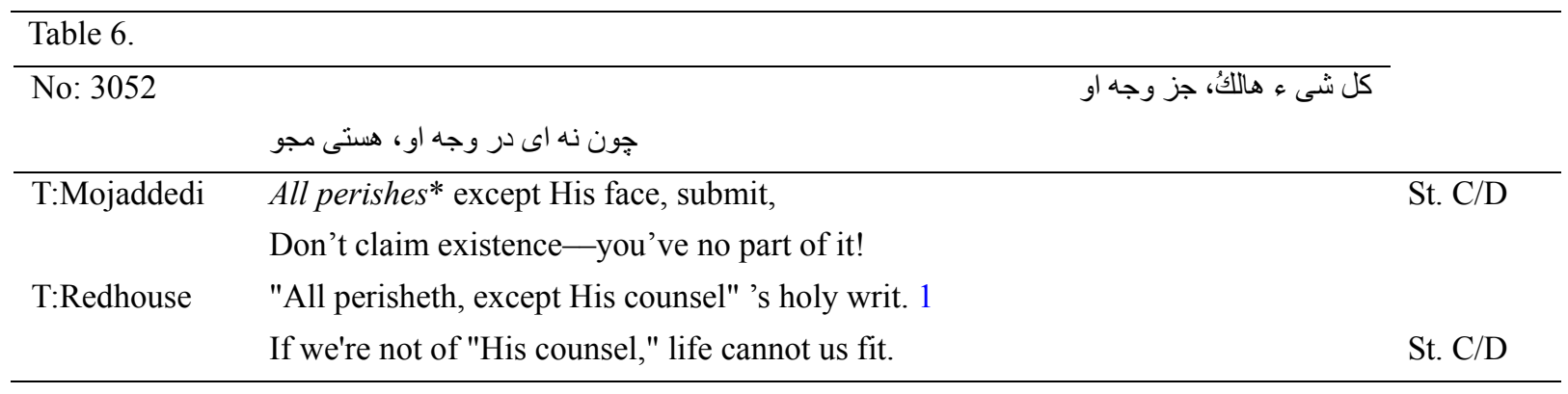


Table 7.

\begin{tabular}{|c|c|c|}
\hline \multirow[t]{2}{*}{ No: 3053} & & هر كه اندر وجه ما باثند فنا \\
\hline & \multicolumn{2}{|l|}{ 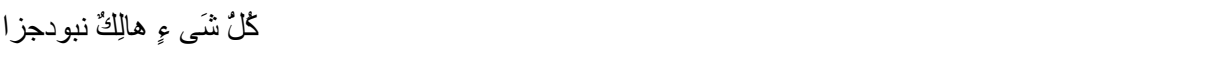 } \\
\hline \multirow{2}{*}{ T:Mojaddedi } & To whomsoever in My face should die & St. C \\
\hline & The rule All perishes does not apply: & \\
\hline \multirow[t]{2}{*}{$\mathrm{T}:$ Redhouse } & He that will lose his life for God's sake, hath it still; & \\
\hline & "All perisheth" hath then no power his soul to kill. & St. C \\
\hline
\end{tabular}

Table 8.

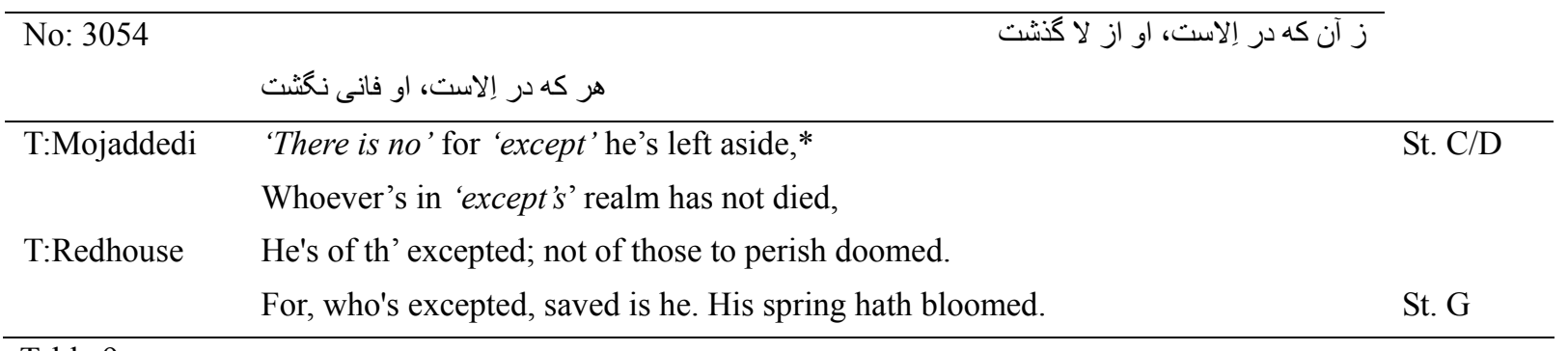

Table 9.

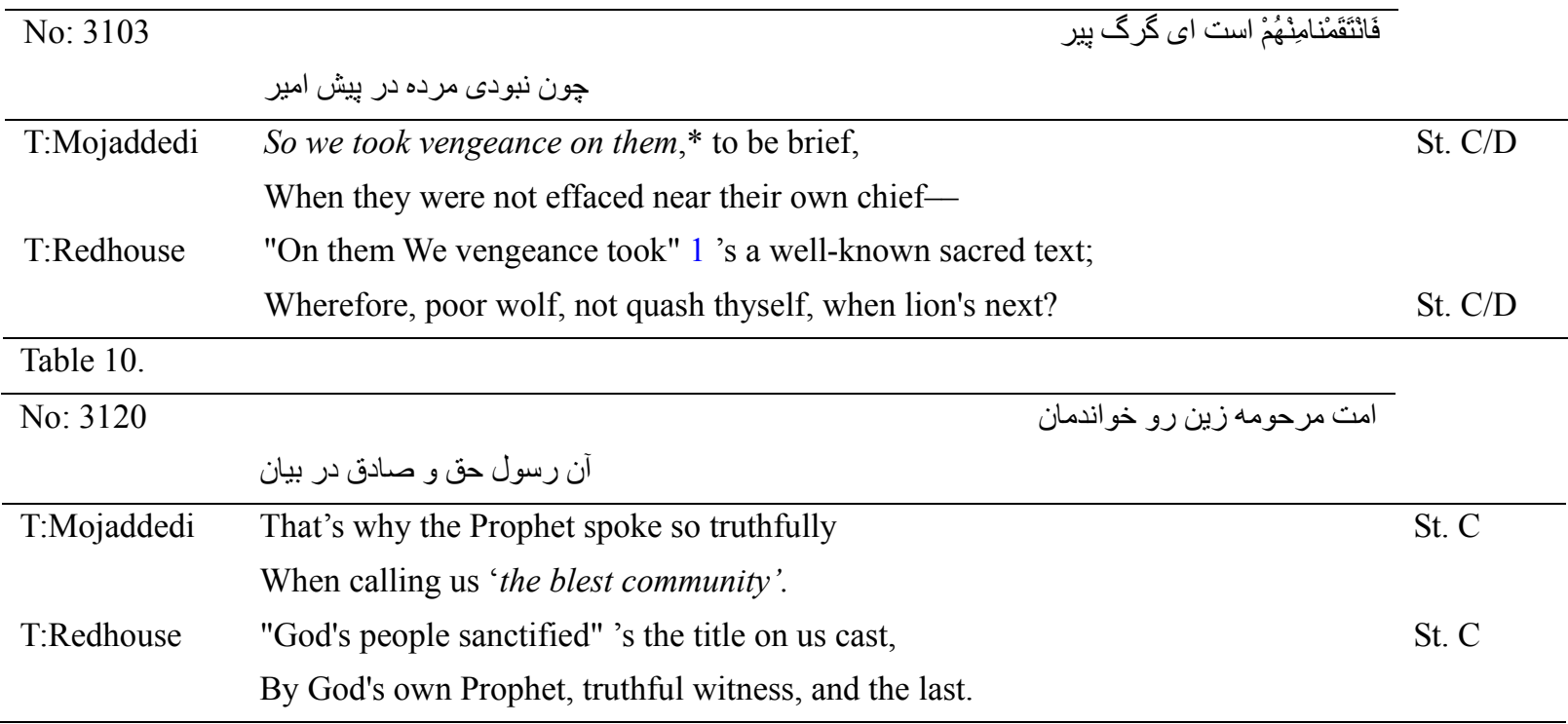

Table 11.

No: 3121

بنكريد و بند كيريد اى مهان

\begin{tabular}{llc}
\hline T:Mojaddedi & Look at the dead wolves' bones and fur, and then & St. B \\
& Consider this a warning, worthy men! & \\
T:Redhouse & $\begin{array}{l}\text { The bones, the skeletons of all those old-world wolves, } \\
\text { Consider well, ye readers; - think upon yourselves. }\end{array}$ & St. B \\
\hline
\end{tabular}

Explanatory notes by Mojaddedi

3032 Consult them too!: Koran 3: 159, in God's address to the Prophet advising him to consult his followers.

3050 Those who think ill of God: Koran 48: 6, in a passage referring to those bound for hellfire because of unbelief.

3065 All perishes: Koran 28: 88; see note to v. 3067.

3067 'There is no' for 'except' he's left aside: allusion to Koran 28: 88, where one is instructed not to pray to any other gods, because There is no god other than He and Everything perishes apart from His face. 
3116 So we took vengeance on them: Koran 7: 136, 15: 79 and 43: 25, concerningthe punishment dealt out to the disobedient.

Footnotes by Redhouse

m218:1 Qur'ān iii. 153.

m219:1 Qur'ān xlviii. 6.

m220:1 Qur'ān xxviii. 88.

m224:1 Qur'ān vii. 132.

m226:1 See Tale iv., dist. 121.

Table 12. Frequency of the strategies used by Mojaddedi

\begin{tabular}{lllllllllll}
\hline Strategies used by Mojaddei & A & B & C & D & E & F & G & H & Both C\&D \\
\hline Frequency \% & 0 & 18.18182 & 18.18182 & 0 & 0 & 0 & 18.18182 & 0 & 0 & 45.45455 \\
\hline Table13. Frequency of the strategies used by Redhouse & & & & & & \\
\hline Strategies used by Redhouse & A & B & C & D & E & F & G & H & I & Both C\&D \\
\hline Frequency\% & 0 & 18.18182 & 18.18182 & 0 & 0 & 0 & 27.27273 & 0 & 0 & 36.36364 \\
\hline
\end{tabular}

\section{Discussion of Results}

With the consideration of Leppihalme's Strategies on translating KP alusions, "The wolf and the fox go to the hunt in attendance on the lion", one of the poems of Mathnawi in book one was compared with its two translations in English and the frequency of each strategy was found. Among these 9 strategies, only 3 of them are used by Mojaddei and Redhouse(1881) and they are B, C and G. Strategy D has been used too, but in combination with $\mathrm{C}$ so the researchers have added a tenth column that is both $\mathrm{C} \& \mathrm{D}$ Which has the highest frequency.

To make an example of the use of strategy C\&D, have a look at 3037 in table 4.As it can be seen, the KP allusion is Italicized by Mojaddedi(2004) and beside it an asterisk *is found. The use of italic refers to the strategy $\mathrm{C}$ and asterisk*to the strategy D. Mojaddei at the end of his book has some explanatory notes which give the exact source of all these KP allusions which are related to Koran or else. On the other hand, Redhouse(1881) has used inverted commas around that KP allusion and immediately after it there's number1 which refers to a foot note. The footnotes by Redhouse(1881) are at the end of each poem.

As it was seen above and is observable in tables $(2,4,6,8,9)$, most of these KP allusions which have used C/D strategy are verses from Koran. So the researchers believe that another strategy can be added to and that is the combination of both $\mathrm{C} / \mathrm{D}$. They think that this strategy is mostly used about religious allusions especially verses from Koran. But they believe more analysis on other poems should be done in order to get sure about this strategy.

There are some KP allusions that refer to verses but the strategy $\mathrm{C} / \mathrm{D}$ or only $\mathrm{C}$ has not been used .It seems that the translator/s have recognized those KP allusions, but have preferred the strategy $\mathrm{G}$ and translated them to their sense, they are 3017 and 3041.

3017refers to a tradition (Hadith) "الجماعـة رحمة وفى الفرقة عذاب".It seems that it has been correctly translated to its sense by the two translators, but it is not clear that it refers to a tradition and only a person familiar by this tradition can recognize the existence of allusion.

3041 is related to the verse 182 of Surah Al-A'raf which says "Those who reject Our Ayat (proofs, evidences, verses, lessons, signs, revelations, etc.), we shall gradually seize them with punishment in ways they perceive not". In fact God's punishment is riches and blessings to people, but people do not understand that's a punishment. So in another look in translations of 3041, it can be seen that the translators have recognized those allusions correctly and have translated them to their sense.

There are two cases which seems the translators have not recognized the existence of allusion and they are 3021 , 3121 .

3021 refers to part of the verse 18 of Surah Al-Kahf which says “....and their dog stretching forth his two forelegs at the entrance ...”.But in both of the translations the word سفَ been translated to a usual dog, look at table 3.

3121refers to part of the verse 36 of Surah An-Nahl which says “... So travel through the land and see what was the end of those who denied (the truth).' In a closer look at the translations of 3121 , it can be observed that the 
connotation of the meanings is different from what exists in verse 36 .

In both of these two cases, the translators without regard to the allusion have translated them literally. But it's worth mentioning that even this kind of strategy has not changed the meaning of the alluded part.

\section{Concluding Remarks}

As allusions are culture-bound elements, they cannot be rendered simply to other languages. Like other cultural-bound terms, KP allusions may remain unclear in their translations because they may refer to some special events, places, and people etc. which have an origin in the source text. In the comparison of KP allusions in a poem in Mathnawi with its two translations, it was found that the most common strategy for rendering them to English was strategy $C \& D$. In fact the translators have both italicized and marked the translation of this type of allusion and after that have added footnotes or endnotes. It is may be due to the fact that most of the KP allusions in Mathnawi are verses of Koran. The researchers believe that the verses of Koran have some subtle points within which cannot be transferred exactly by translation.Molavi has used these verses beautifully in his poems for different purposes. So, marking and italicizing them in translation may be the best strategy to make the reader eager to refer to the original sources for getting the exact or closest meanings.

\section{References}

Bahrami, N. (2012). Strategies used in the translation of allusions in Hafiz Shirazi's poetry. Journal of Language and Culture, 3(1), 1-9.

Cordero, A. D. (1984). An experiment on loss in translation. ATA Silver Tongues: American Translators' Association Conference 1984 (pp. 471-476). Proceedings of the 25th Annual Conference of the ATA. New York: Learned Information.

Leppihalme, R. (1997). Culture Bumps: An Empirical Approach to the Translation of Allusions. Cleve don: Multilingual MattersLtd.

Mojaddedi, J. (2004). Jalal Al-Din Rumi the Masnavi book one. New York: Oxford University Press Inc.

Montgomery, M. (2000).Ways of Reading: Advanced Reading Skills for Students of English literature. London: Rutledge.

Niknasab, L. (2011). Translation and Culture: Allusions as Culture Bumps. SKASE Journal of Translation and Interpretation, 5(1), 45-54.

Pirnajmuddin, H., \& Niknasab, L. (2011). Translating political allusions: a survey of a portrait of the artist as a young man by James Joyce. Theory and Practice in Language Studies, 1(7), 851-860. $\mathrm{http}: / / \mathrm{dx}$.doi.org/10.4304/tpls.1.7.851-860

Redhouse, J. W. (1881). The Mesnevi (Usually Known as the Mesneviyi Sheriff, or Holy Mesnevi) of Mevlana (Our Lord) Jelalu- 'D-Din, Muhammed, Er-Rumi. Book the First. London: Trubner \& Co.,Ludgate hill.

Ruokonen, M. (2010). Cultural and textual properties in the translation and interpretation of allusions. An analysis of allusions in Dorothy L. Sayers' detective novels translated into Finnish in the 1940s and the 1980s. Annales Universitatis Turkuensis B 330. Turku: University of Turku.

Sahebhonar, S. (2006). An intertextual consideration of proper name allusions in two English Readings of Rumi's Mathnavi. M.A.Thesis Esfahan University. English Department.

Vahid Dastjerdi, H., \& Sahebhonar, S. (2008). Lost in translation: An intertextual study of personal proper-name allusions. Across Languages and Cultures, 9(1), 41-56. http://dx.doi.org/10.1556/Acr.9.2008.1.3

Wheeler, M. (1979). The Art of Allusion in Victorian Fiction. UK: Macmillan Press Ltd. 